Article

\title{
Tourist Intensity in the World, 1995-2015: Two Measurement Proposals
}

\author{
Carles Manera * and Elisabeth Valle
}

Facultad de Economía, Edificio Jovellanos, Universitat De Les Illes Balears, 07122 Palma de Mallorca, Spain; elisabeth.valle@uib.es

* Correspondence: carles.manera@uib.es; Tel.: +34-601118822

Received: 11 October 2018; Accepted: 18 November 2018; Published: 2 December 2018

\begin{abstract}
The work emphasizes the importance of measuring the tourist intensity of the economies that are oriented to tourism activity, with the aim of avoiding subjective arguments and being more related to perception than with the empirical contrast of the data. A tourist intensity index is proposed, which is made up of four essential variables: GDP, tourist spending, population, and the number of tourists. However, at the same time, it is complemented by a measure of tourist density, which helps to better understand the proposed index. This allows for the classification of countries according to the resulting index, and to calibrate their position in the set of tourist economies. This can be very useful for the application of economic policies aimed at correcting externalities that are generated in the advanced development of mass tourism.
\end{abstract}

Keywords: mass tourism; tourist intensity; tourist density

\section{Introduction}

A concept that has been disseminated insistently in recent times is that of saturation and/or intensity in the leading mass tourism economies, after the great boom in tourism economy as of 1950 [1]. The media have echoed this issue with certain insistence, often times using arguments and experiences of a subjective nature - which are not to be ignored - but with a lack of reliable empirical data to allow reasonable - and homogenised — contrast between different geographic areas. Indeed, despite the importance of tourism on an international scale, there is no single consensus regarding how to measure tourism intensity. This is understood, by some authors, as the number of overnight stays per resident [2-4]; while others adduce the number of tourist arrivals and overnight stays $[5,6]$. In both cases, the models are basically related to the life cycle of the tourism product [7], in its different stages of development. There are also contributions from study cases of tourism destinations with high intensities, in order to identify threats and possible innovative solutions. In each contribution, the definition of tourism intensity is different: it may be the relationships of tourists with respect to the permanent population; or the number of annual tourists divided by the $\mathrm{km}^{2}$ of territory; sometimes, it is even calculated as overnight stays per 1000 inhabitants, or number of arrivals per 100 inhabitants [8-14].

At the same time, empirical contributions concerning the sustainability of tourism-besides the theoretical contributions in this field-incorporate decisive elements for analysing the sector. From the abundant bibliography available, we highlight these recent contributions: [15-22]. In short, intensity, saturation, and sustainability-and even, the notion of governance-have ended up being concepts that are increasingly used by social scientists to analyse tourism phenomena [23-30]. This methodologically disparate situation is what justifies the main purpose of this research: the proposal of two specific instruments for measuring tourism intensity. (There exists important official documentation regarding tourism intensity. By way of example, [31-35]. Bed count and/or overnight stays are usually the 
indicators used.) The methodological justification lies in the fact that we do not have precise indicators to measure tourism intensity and, above all, we do not have them as composite indicators. We can observe the tourist evolution with parameters such as the number of visitors, overnight stays, and even tourist spending. However, we have not detected the composition of synthetic indices that group different variables, and that the result is satisfactory in two directions: first, the possibility of having a ranking of tourist intensity; and second, that these results open new perspectives for research.

First of all, the formulation of a Tourism Intensity Index (TII). To this effect, four large dimensions will be adopted, based on information published by the World Tourism Organisation (WTO), corresponding to the period from 1995 to 2015, worldwide. These four dimensions are the number of tourists a destination receives, its total population, as well as tourism revenue, and the GDP of the economy considered. The study follows on from a previous one [36], in which a tourism intensity index was provided, and was applied to 18 island economies throughout the world, thereby revealing a ranking based on the data-GDP, tourism spending, population, and number of tourists-extracted from the statistical institutions in the observed regions. We believe the contribution offered in this new paper, which is based on the aforementioned factors, improves on the former, as it uses a homogeneous source from the WTO, thereby leading to more robust results.

Secondly, a measure of Tourism Density (TD), that is, the number of tourists per $\mathrm{km}^{2}$, which complements the TII. If we multiply the demographic component of the TII by the population ratio per $\mathrm{km}^{2}$ of the country, this tourism density will be obtained. This calculation is reached by combining the information from the WTO with that gathered from the World Bank regarding the population and number of $\mathrm{km}^{2}$ for each of the countries.

The virtue of these two indices is that they involve different variables and not only one or two, as found in the aforementioned reference contributions, which have defined much of the research conducted on the evolution of mass tourism in this specific field. Such indicators are correct. Yet, the new indices we propose contribute three basic virtues. Firstly, they constitute a methodological innovation, by introducing, in a single synthetic index, four determining variables that are closer to the economic reality of the territory considered. Secondly, they facilitate their application on an international, national, and regional scale, in order, thereby, to establish comparisons, hence the scale of analysis is equally broad. Thirdly, the results open up new pathways for research, not only in the field of tourism, but also for studying economic structures (for an interesting analysis in this direction for Spanish regions, see [37]).

The article is organised as follows. In the first section, the important development of tourism economy in the world since the 1950s is set forth, a prime example of a technical-economic change with services at the epicentre [38]. The second section focuses on the methodological proposal and the results obtained concerning a Tourism Intensity Index (TII), which uses the four aforementioned key vectors to understand tourism economy; and a Tourism Density index (TD) which is based on intensity as a function of the area of the destination, such that it complements the former. The paper closes with some final reflections that, additionally, summarise the main contributions of the study.

The starting hypothesis of the research is that there are tourist intensities of great relevance, affecting mainly island economies around the world. On the other hand, the construction of tourist intensity indexes promotes a scientific basis to validate possible processes of sustainability or unsustainability of a territory. The results obtained in the research are satisfactory in this regard, as can be consulted in the conclusions of the investigation.

The connection of our research with the fundamental idea of sustainability lies in an essential methodological aspect: to provide measurable indicators, with variables of public access, that open new perspectives for future research. We can see how we have obtained a ranking of countries based on the proposed indexes and, at the same time, this allows us to flee from subjective conceptions and contribute more and better scientific findings about the phenomenon of sustainability. Now, it may be clearer to venture, with new indicators of a biophysical nature, if the panel of countries that have emerged from our indexes confirm processes of environmental sustainability. However, from 
the outset, we do know that these countries constitute, in the field of tourism economy, those that, in principle, may have greater problems of spatial and demographic congestion. These two elements we consider are key to the sustainability of a territory.

\section{Tourism, an Industry in Expansion}

Tourism is one of the most important and dynamic economic activities of our days, recording remarkable growth since the immediate post-war period. The progression of the number of tourists between 1950 and 2018 is striking [36,39-41]. The perspective of economic history points towards a loss of tourism strength in Europe and America as destinations. In 1950, 97\% of world tourism was aimed at these continents. By the turn of the 21st century, the proportion had decreased to $70-80 \%$ and, according to the forecasts of the UNWTO, this figure will have dropped to $64 \%$ by 2020 [42]. At the other end of the spectrum, we find the Asia and Pacific areas, which have gained greater prominence, with an outlook of $27 \%$ in 2020. Similar conclusions are reached for the East and Africa, which have doubled-and are expected to increase - their function as a world tourism destination. Hence, it is possible to observe a loss of market share for Europe and America and a certain "peripheralisation" of tourism expansion [43,44].

According to [45], the number of international tourist arrivals grew 3.9\% in 2016, to reach 1235 million worldwide. It was the seventh consecutive year of above-average growth, after the Great Recession that began in 2008. This growth is sustained, on the one hand, by an increase in disposable personal income; and, on the other hand, by certain sociodemographic changes that are taking place in the most advanced countries, such as the rise in couples without children and single family homes, better standards of education, a higher proportion of older people, and an increase in the number of retirees [46]. International tourist arrivals worldwide could increase $3.3 \%$ a year between 2010 and 2030, to reach 1800 million in 2030, according to the long-term forecast listed in the UNWTO report [47].

Nonetheless, three objections can be made to these optimistic perspectives. First of all, a decrease in tourism spending at the destination. The tourism-spending variable is a concept that is affected by fluctuations in exchange rates and by an increase in prices of tourism products. However, the trend appearing over the last decade seems to be clear: a reduction in the length of stay at the destination [48,49]. Among the causes of these shorter stays, it is worth noting a greater frequency of international trips, which is associated with a reduction of the length of each one; a preference of tourists for higher quality holidays, which means giving up on longer stays; and the existence of a price effect, which could lead to a reduction of the time of stay at the destination. Secondly, symptoms of maturity in tourism demand in certain countries. Observation of outbound tourism points towards a possible stagnation - in source markets of developed countries—of the percentage of the population making trips abroad. The cases of France and Great Britain are illustrative: the rise in tourism demand is due to a greater frequency of trips per year by frequent travellers. In this sense, since 1990, the world regions that have enlarged outbound tourism have mostly been Asia and the Pacific, and the Middle East [50,51]. Europe and America have increased their figures more slowly. Finally, it is worth noting new consumer tastes [52]. This customer-described as "post-Fordist"—has interests that differ from crowded sun and beach places and, therefore, represents a serious threat to mass tourism destinations. In France, but especially in Great Britain (and also in Germany), the reduction of social benefits and continuous vacation time has encouraged the adoption of new patterns of tourist consumption. That is to say: shorter trips, but more frequent. These cases represent a model of tourist consumption that especially affects sun and beach destinations, the most demanded by British, French, and German tourists. They are examples that can be extended to other countries and destinations.

At any rate, tourism growth is expansive, measured by an indicator as eloquent as the number of visitors in a certain area. Tourism becomes imitative the moment its first successes crystallise: unconscious talent flows, emulation expands, and chaotic, disorganised beginnings give way to submission to practical rules of operation of the new activity. The turnaround becomes evident: 
national or regional economies show patent signs in the structures of their labour markets, and in the gradual contribution of the emerging activity in generating income. All this was coined in a peculiar expression applied to developing economies: "pleasure peripheries" [53]. According to this, these peripheries are tourism ghettos located in lagging regions that, since the 1970s, have proliferated under two essential conditions: good air connectivity and the availability of many hours of sunshine. These areas, close to the coast and, in some way, blinded, surrounded centres that were generally poor and poorly connected to other more privileged areas. (Examples that can be cited are Port-au-Prince, Nassau, San Juan de Puerto Rico, Acapulco, Cancun, Hawaii as peripheral areas frequented by North-American tourists; Mallorca, Ibiza, Benidorm, the Canary Islands, Torremolinos, more visited by Europeans, without forgetting, in these cases, other destinations such as Nice, Monte Carlo, Cannes, Venice, and Florence; and the Philippines, Hong Kong, Bangkok, and Bali, as the preferences of the Japanese [53]). However, these so-called peripheries do not have similar evolutions-because their historical trajectories are heterogeneous - neither can they be explained by tourism models of a generalist nature that satisfy all of them in their different chronologies. Ref. [54] aims to lay down some common coordinates to these peripheries, based on the theory of dependence and by relating their tourism trajectories to the general dynamics of capitalism. There exists, in this contribution, a clear interest in coding the behaviours of the tourism areas considered, from the structuralist matrix of the aforementioned theory. We totally disagree with this unifying sense. Measuring these evolutions is feasible based on the two instruments proposed below.

\section{Presentation of the Indices: Methodology and Results}

The authors define two different indices, the Tourism Intensity Index and the Tourism Density. The Tourism Intensity Index (TII) adopts demographic and economic variables obtained from the WTO for all countries. This ensures the homogeneity of the selection of the variables for drawing up the index. Namely, this is defined as follows:

$$
\text { Tourism Intensity Index } x^{i}=\sqrt{\frac{\frac{T_{i}}{P_{i}}}{\frac{T_{w}}{P_{w}}} \times \frac{\frac{T_{i}}{G D P_{i}}}{\frac{T R_{w}}{G D P_{w}}}} \times 100,
$$

where $\mathrm{T}$ is the number of tourists, $\mathrm{P}$ the population, TR tourism revenue, GDP the gross domestic product, and the subscript $\mathrm{i}$ is used for a specific country, and $\mathrm{w}$ for the world. The WTO provides, amongst many other indicators and always from a general perspective, the relationship between the amount of inbound and domestic tourism and the population, as well as the percentage of the GDP of inbound tourism spending from 1995 to 2015 for all the countries in the world. It must be indicated, however, that these data are not always available and, occasionally, neither are they available for the same country for all the years analysed. This led to a methodological problem that we attempted to solve by focusing on the trends of the series.

While carrying out the calculation of the TII, we added a new geographical aspect: the Tourism Density (TD) of the country, that is, the number of tourists per $\mathrm{km}^{2}$ :

$$
\mathrm{TD}=\frac{\text { Inbound tourism }+ \text { Domestic tourism }}{\text { Population }} \times \frac{\text { Population }}{\mathrm{km}^{2}}=\frac{\text { Inbound tourism }+ \text { Domestic tourism }}{\mathrm{km}^{2}}
$$

If the demographic component of the TII is multiplied by the population ratio per $\mathrm{km}^{2}$ of the country, the tourism density will be obtained. This calculation is reached by combining the information from the WTO with that gathered from the World Bank concerning the population and number of $\mathrm{km}^{2}$ for each of the countries.

Having defined the contents of the two indices, the calculation of the TII for all the countries between 1995 and 2015 is presented below. Countries were ranked from greater to lower tourism intensity, depending on the mean value of the indicator over this period, and were classified according to whether they had a very high TII (mean greater than 1500), a high TII (mean lower than 1500 and 
over 500), a medium TII (mean lower than 500 and greater than 100), or a low TII (mean lower than 100). This enabled us to obtain four large blocks of countries by comparing to 100 , which would be the average world value. Let us look at this in greater detail.

\subsection{Countries with a Very High Tourism Intensity Index}

The countries classified as having a very high TII are the ones listed in Table 1.

Table 1. Very high Tourism Intensity Index (mean value 1995-2015).

\begin{tabular}{cc}
\hline COUNTRY & TII \\
\hline & Mean Value 1995-2015 \\
\hline Macao, China & 6.656 \\
Aruba & 3.720 \\
Anguilla & 2.654 \\
Bahamas & 2.164 \\
Maldives & 2.077 \\
Antigua and Barbuda & 1.944 \\
\hline Source: own work. Data source: World Tourism Organization.
\end{tabular}

In Figure 1, the set of countries with the greatest TII and the evolution of these indicators from 1995 to 2015 can be observed.

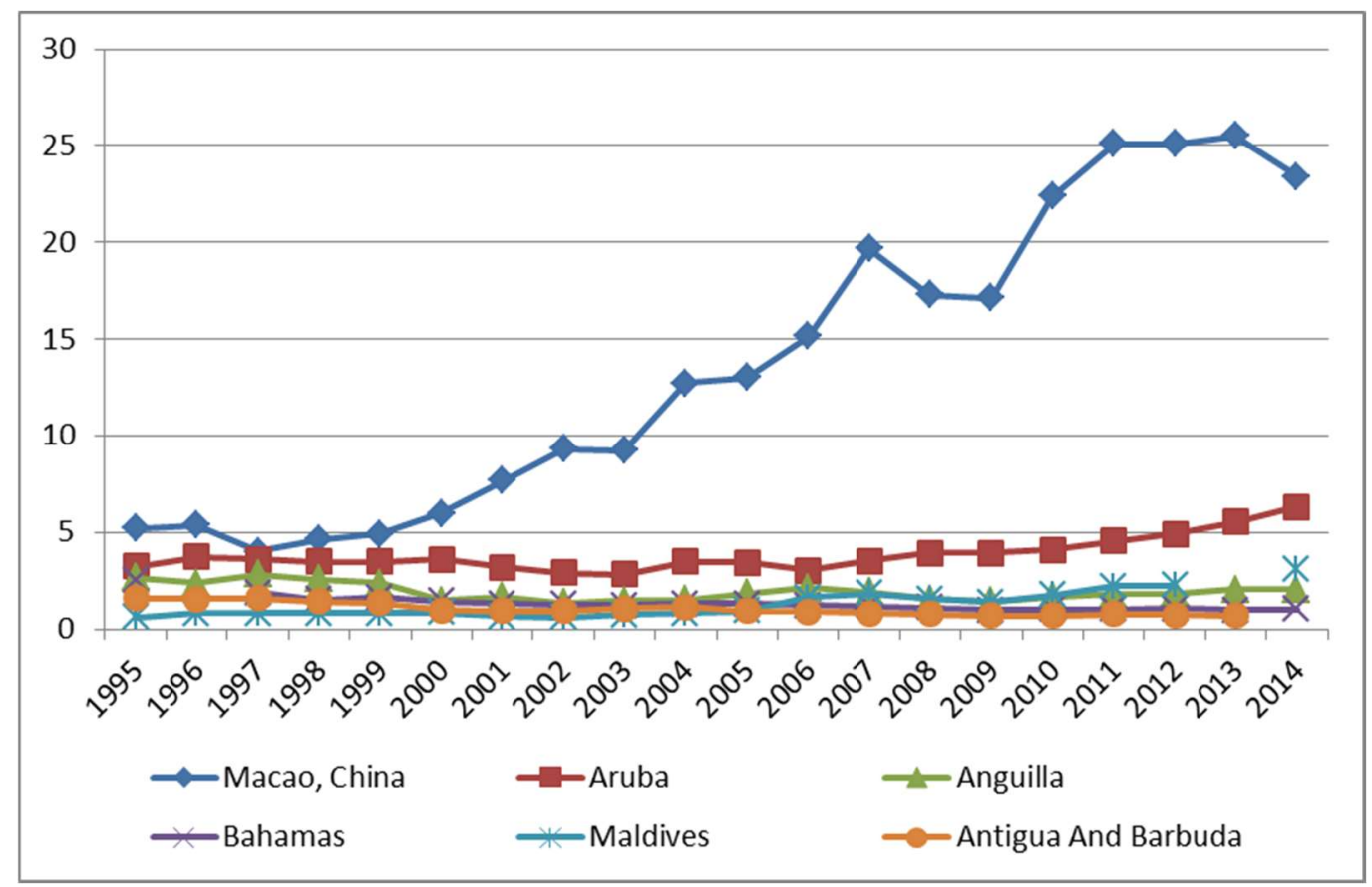

Figure 1. Very high Tourism Intensity Index evolution. Source: own work. Data source: World Tourism Organization.

The interpretation of these materials is clear: except for the territory of Macau (made up of the mainland of Macau, connected to Asia, and the two islands of Taipa and Coloane), the rest are archipelagos located in the Caribbean (Anguilla, Antigua and Barbuda, Aruba, and the Bahamas) and the Maldives in the Indian Ocean. All of these have the highest TII and, by far, the greatest in this group, we find to be Macau, one of the largest gambling centres in the world, followed by Aruba, which boasts the best casinos in the Caribbean.

In Table 2, the two basic components of the very high TII are broken down, by country, for 2014 (it must be noted that for 2015, much of the data is still not yet available). Both Macau and the Maldives 
reveal a dependency on tourism spending that is greater than $90 \%$ of their GDP; but the large number of tourists, with respect to the population produced in Macau, places it in the first position, far ahead of Aruba, in second place.

Table 2. Basic components of the very high TII.

\begin{tabular}{ccc}
\hline & (Tourism/Population) (Ti/Pi) & Tourism Revenue/GDP (TRi/GDPi)—\% \\
\hline COUNTRY & $\mathbf{2 0 1 4}$ & $\mathbf{2 0 1 4}$ \\
\hline Macao, China & 25.20 & 92.9 \\
Aruba & 10.36 & 61.0 \\
Anguilla & 4.91 & 41.8 \\
Bahamas & 3.73 & 27.0 \\
Maldives & 3.37 & 91.7 \\
\hline
\end{tabular}

There is no 2014 data in the case of Antigua and Barbuda. Source: own work. Data source: World Tourism Organization.

\subsection{Countries with a High Tourism Intensity Index}

The countries classified with a high TII are the ones given in Table 3. Standing out in this group are many archipelagos that are famous for their tourism industry: Barbados, Bahrain, Belize, Dominica, Fiji, Grenada, Jamaica, Malaysia, Mauritius, Montserrat, Saint Lucia, Saint Kitts and Nevis, Seychelles; and, also, countries such as Austria, Croatia, Spain, the United States, Estonia, France, Greece, and Hong Kong, among others.

Table 3. High Tourism Intensity Index (mean value 1995-2015).

\begin{tabular}{|c|c|c|c|}
\hline COUNTRY & TII & COUNTRY & TII \\
\hline & Mean Value 1995-2015 & & Mean Value 1995-2015 \\
\hline Seychelles & 1.501 & Hungary & 697 \\
\hline Bahrain & 1.419 & Belize & 690 \\
\hline Saint Lucia & 1.419 & Fiji & 677 \\
\hline Croatia & 1.413 & Czech Republic & 677 \\
\hline Barbados & 1.360 & Saint Vincent and the Grenadines & 671 \\
\hline Cyprus & 1.203 & Ireland & 667 \\
\hline Saint Kitts and Nevis & 1.157 & Greece & 659 \\
\hline Montenegro & 982 & Cambodia & 619 \\
\hline Montserrat & 969 & Mauritius & 608 \\
\hline Australia & 925 & Finland & 603 \\
\hline Grenada & 866 & Uruguay & 598 \\
\hline New Zealand & 866 & Singapore & 589 \\
\hline Hong Kong, China & 852 & Slovenia & 586 \\
\hline Spain & 847 & Jamaica & 584 \\
\hline Estonia & 813 & France & 580 \\
\hline Austria & 811 & Vanuatu & 579 \\
\hline Dominica & 809 & Samoa & 578 \\
\hline Taiwan Province of China & 804 & United States of America & 513 \\
\hline Malaysia & 789 & Iceland & 509 \\
\hline Luxembourg & 758 & Norway & 501 \\
\hline Thailand & 711 & & \\
\hline
\end{tabular}

Source: own work. Data source: World Tourism Organization.

In Table 4, the five-year evolution of the TII is given, from 1995 to 2015, for the group of countries whose mean value for the period is greater than 500 and less than 1500 . 
Table 4. Five-year evolution of the high Tourism Intensity Index.

\begin{tabular}{|c|c|c|c|c|c|}
\hline COUNTRY & 1995 & 2000 & 2005 & 2010 & 2015 \\
\hline Seychelles & 1.895 & 1.508 & 1.175 & 1.588 & \\
\hline Bahrain & 1.473 & 1.468 & 1.548 & 1.725 & \\
\hline Saint Lucia & 1.809 & 1.554 & 1.596 & 1.258 & \\
\hline Croatia & & & & 1.316 & 1.515 \\
\hline Barbados & 1.703 & 1.361 & 1.342 & 1.305 & \\
\hline Cyprus & & & 1.269 & & \\
\hline Saint Kitts and Nevis & 1.616 & 930 & 1.440 & 948 & \\
\hline Montenegro & & & & 1.097 & \\
\hline Montserrat & 1.592 & 1.425 & 1.101 & 690 & \\
\hline Australia & & & & 966 & 960 \\
\hline Grenada & 1.236 & 941 & 564 & 751 & \\
\hline New Zealand & & & & 831 & \\
\hline Hong Kong, China & & 492 & 724 & 1.124 & 1.259 \\
\hline Spain & & 1.008 & 819 & 775 & 837 \\
\hline Estonia & & & & 818 & 1.065 \\
\hline Austria & & & & 829 & 826 \\
\hline Dominica & 909 & 748 & 748 & 873 & \\
\hline Taiwan Province of China & & & & 694 & 914 \\
\hline Malaysia & & & & 800 & 810 \\
\hline Luxembourg & & & & 736 & 745 \\
\hline Thailand & & & & 697 & \\
\hline Hungary & & & & 717 & 737 \\
\hline Belize & 641 & 642 & 722 & 725 & \\
\hline Fiji & 634 & 494 & 722 & 845 & \\
\hline Czech Republic & & & 681 & 705 & 624 \\
\hline $\begin{array}{c}\text { Saint Vincent and the } \\
\text { Grenadines }\end{array}$ & 756 & 739 & 735 & 554 & \\
\hline Ireland & & & & 658 & 753 \\
\hline Greece & & & 667 & 558 & 826 \\
\hline Cambodia & & & & 621 & \\
\hline Mauritius & 543 & 582 & 608 & 672 & 644 \\
\hline Finland & & 547 & 561 & 694 & \\
\hline Uruguay & & & & 629 & 543 \\
\hline Singapore & 884 & 568 & 498 & 631 & \\
\hline Slovenia & & 576 & 544 & 629 & 637 \\
\hline Jamaica & 660 & 591 & 533 & 641 & 637 \\
\hline France & & & 597 & 583 & 548 \\
\hline Vanuatu & 506 & 587 & 503 & 724 & \\
\hline Samoa & 606 & 591 & & & \\
\hline United States of America & & & & 520 & 550 \\
\hline Iceland & 402 & 426 & 393 & 491 & 1081 \\
\hline Norway & & & & 512 & 494 \\
\hline
\end{tabular}

Source: own work. Data source: World Tourism Organization.

In Table 5, the TII components for 2014 are broken down into their demographic and economic aspects. From the demographic point of view, the greatest pressure is received by Australia, followed by Bahrain and Taiwan, whereas, at the economic level, Seychelles reveals the greatest dependency followed by Saint Lucia, Dominica, Fiji, and Belize (it should be noted that for some countries, there are no data available in 2014). 
Table 5. Basic components of the high TII.

\begin{tabular}{|c|c|c|c|c|c|}
\hline & $\begin{array}{c}\text { (Tourism/ } \\
\text { Population) } \\
\text { (Ti/Pi) }\end{array}$ & $\begin{array}{c}\text { Tourism } \\
\text { Revenue/ GDP } \\
\text { (TRi/GDPi)—\% }\end{array}$ & & $\begin{array}{c}\text { (Tourism/ } \\
\text { Population) } \\
\text { (Ti/Pi) }\end{array}$ & $\begin{array}{c}\text { Tourism } \\
\text { Revenue/ GDP } \\
\text { (TRi/GDPi)_\% }\end{array}$ \\
\hline COUNTRY & 2014 & 2014 & COUNTRY & 2014 & 2014 \\
\hline Seychelles & 2.43 & 31.8 & Hungary & 2.73 & 5.4 \\
\hline Bahrain & 7.67 & 5.7 & Belize & 0.91 & 22.1 \\
\hline Saint Lucia & 1.84 & 28.6 & Fiji & 0.78 & 22.8 \\
\hline Croatia & 4.00 & 17.6 & Czech Republic & 3.58 & 3.7 \\
\hline Cyprus & 3.24 & 12.5 & $\begin{array}{c}\text { Saint Vincent and the } \\
\text { Grenadines }\end{array}$ & 0.65 & 12.8 \\
\hline Saint Kitts and Nevis & 2.06 & 15.1 & Ireland & 3.81 & 4.4 \\
\hline Montenegro & 2.16 & 20.8 & Greece & 2.34 & 8.2 \\
\hline Montserrat & 1.73 & 13.0 & Cambodia & 0.88 & 19.2 \\
\hline Australia & 10.70 & 2.4 & Mauritius & 0.82 & 13.6 \\
\hline Grenada & 1.26 & 15.8 & Uruguay & 2.33 & 3.5 \\
\hline Hong Kong, China & 3.84 & 15.8 & Singapore & 2.15 & 6.2 \\
\hline Spain & 4.42 & 4.6 & Slovenia & 2.08 & 5.9 \\
\hline Estonia & 4.17 & 8.6 & Jamaica & 0.75 & 16.2 \\
\hline Austria & 4.32 & 4.8 & France & 4.37 & 2.3 \\
\hline Dominica & 1.13 & 23.6 & United States of America & 6.84 & 1.4 \\
\hline Taiwan Province of China & 7.09 & 3.3 & Iceland & 3.05 & 8.0 \\
\hline Malaysia & 3.32 & 6.7 & Norway & 5.73 & 1.3 \\
\hline Luxembourg & 2.05 & 9.6 & & & \\
\hline
\end{tabular}

There are no complete 2014 dates in the case of Barbados, New Zealand, Thailand, Finland, Vanuatu, and Samoa. Source: own work. Data source: World Tourism Organization.

\subsection{Countries with a Medium Tourism Intensity Index}

The countries classified as having a medium TII are shown in Table 6.

Table 6. Medium Tourism Intensity Index (mean value 1995-2015).

\begin{tabular}{cccc}
\hline COUNTRY & TII & COUNTRY & TII \\
\hline Jordan & Mean Value 1995-2015 & & Mean Value 1995-2015 \\
\hline Switzerland & 491 & Philippines & 243 \\
Republic of Korea & 470 & Japan & 225 \\
Cabo Verde & 465 & Kyrgyzstan & 205 \\
Slovakia & 456 & South Africa & 205 \\
Turkey & 444 & Vietnam & 202 \\
Tunisia & 444 & Indonesia & 199 \\
Lebanon & 422 & China & 198 \\
Italy & 407 & Guyana & 189 \\
United Kingdom & 389 & Israel & 175 \\
Dominican Republic & 386 & Ukraine & 163 \\
Lithuania & 368 & Oman & 163 \\
Canada & 364 & Ecuador & 162 \\
Armenia & 360 & Gambia & 160 \\
Colombia & 353 & Suriname & 154 \\
Belgium & 337 & Brunei Darussalam & 141 \\
Albania & 332 & Mongolia & 138 \\
Botswana & 331 & El Salvador & 135 \\
Romania & 331 & Nicaragua & 124 \\
Poland & 322 & India & 111 \\
Costa Rica & 318 & Honduras & 111 \\
Tonga & 308 & Mexico & 106 \\
Saudi Arabia & 276 & Bosnia and Herzegovina & 105 \\
Panama & 271 & & \\
Qatar & 267 & & \\
\hline & 264 & & \\
\hline
\end{tabular}

Source: own work. Data source: World Tourism Organization.

In Table 7, the five-year evolution of the TII can be observed from 1995 to 2015, for countries whose value for the period is greater than 100 and less than 500. As this is a mean value for the whole 
20-year period, some higher magnitudes for the TII may be found, as this is not a mean value but, rather, the specific value of the TII for that particular year.

Table 7. Five-year evolution of the medium Tourism Intensity Index.

\begin{tabular}{|c|c|c|c|c|c|}
\hline COUNTRY & 1995 & 2000 & 2005 & 2010 & 2015 \\
\hline Jordan & 431 & 378 & 504 & 617 & \\
\hline Switzerland & & & & 466 & 420 \\
\hline Republic of Korea & & & & 418 & 467 \\
\hline Cabo Verde & 148 & 348 & 497 & 767 & \\
\hline Slovakia & & & 437 & 430 & \\
\hline Turkey & & & & 428 & 467 \\
\hline Tunisia & 489 & 461 & 422 & 463 & \\
\hline Lebanon & & 196 & 507 & 621 & \\
\hline Italy & & 447 & 377 & 374 & 336 \\
\hline United Kingdom & & & & 382 & 404 \\
\hline Dominican Republic & 345 & 405 & 369 & 348 & 390 \\
\hline Lithuania & & & 383 & 348 & 347 \\
\hline Canada & & & & 371 & 342 \\
\hline Armenia & & & & 342 & 442 \\
\hline Colombia & & & & 339 & 395 \\
\hline Belgium & & & & 322 & 353 \\
\hline Albania & 44 & 66 & & 645 & 733 \\
\hline Botswana & 252 & 316 & 381 & 450 & \\
\hline Romania & & & & 295 & 344 \\
\hline Poland & & & 319 & 308 & 321 \\
\hline Costa Rica & 274 & 316 & 341 & 320 & \\
\hline Tonga & 275 & 227 & 277 & 355 & \\
\hline Saudi Arabia & & & 266 & 252 & 333 \\
\hline Panama & 167 & 184 & 222 & 350 & 441 \\
\hline Qatar & & 134 & 246 & & \\
\hline Philippines & & & & 208 & 308 \\
\hline Japan & & & & 228 & \\
\hline Kyrgyzstan & & 45 & & 160 & 344 \\
\hline South Africa & & & & 209 & 188 \\
\hline Vietnam & & & 173 & 230 & \\
\hline Indonesia & & & & 193 & 213 \\
\hline China & 180 & 185 & 200 & 213 & \\
\hline Guyana & 200 & 249 & 147 & 162 & \\
\hline Israel & 274 & 234 & 150 & 186 & 150 \\
\hline Ukraine & 44 & 96 & 220 & 243 & 126 \\
\hline Oman & & 138 & 152 & 181 & \\
\hline Ecuador & & & & 186 & 203 \\
\hline Gambia & & & 152 & 129 & \\
\hline Suriname & 193 & 143 & 238 & 152 & \\
\hline Brunei Darussalam & & & 150 & & \\
\hline Mongolia & 78 & 89 & 187 & 169 & \\
\hline El Salvador & 59 & 133 & 154 & 146 & 183 \\
\hline Nicaragua & 71 & 111 & 135 & 153 & \\
\hline India & 72 & 80 & 101 & 139 & 187 \\
\hline Honduras & 73 & 104 & 123 & 130 & \\
\hline Mexico & 163 & 111 & 98 & 93 & 113 \\
\hline Bosnia and Herzegovina & & 93 & 94 & 115 & \\
\hline
\end{tabular}

Source: own work. Data source: World Tourism Organization.

Upon analysing the data in Table 8, the country with the greatest demographic pressure is Korea, followed by Japan; in both cases, economic dependence is small. At the opposite end of the scale, we find Jordan, followed by Albania and Panama, with important economic dependence, but with controlled demographic pressure. 
Table 8. Basic components of the medium TII.

\begin{tabular}{|c|c|c|c|c|c|}
\hline & $\begin{array}{c}\text { (Tourism/ } \\
\text { Population) } \\
\text { (Ti/Pi) }\end{array}$ & $\begin{array}{c}\text { Tourism } \\
\text { Revenue/ GDP } \\
\text { (TRi/GDPi)—\% }\end{array}$ & & $\begin{array}{c}\text { (Tourism/ } \\
\text { Population) } \\
\text { (Ti/Pi) }\end{array}$ & $\begin{array}{c}\text { Tourism } \\
\text { Revenue/ GDP } \\
\text { (TRi/GDPi)_\% }\end{array}$ \\
\hline COUNTRY & 2014 & 2014 & COUNTRY & 2014 & 2014 \\
\hline Jordan & 0.54 & 15.4 & Saudi Arabia & 1.79 & 1.2 \\
\hline Switzerland & 1.91 & 3.0 & Panama & 0.45 & 11.7 \\
\hline Republic of Korea & 4.82 & 1.6 & Qatar & 1.30 & 5.0 \\
\hline Turkey & 1.43 & 4.9 & Philippines & 1.13 & 2.1 \\
\hline Tunisia & 0.64 & 6.4 & Japan & 4.80 & 0.4 \\
\hline Italy & 1.65 & 2.1 & Kyrgyzstan & 0.49 & 6.3 \\
\hline United Kingdom & 2.28 & 2.0 & South Africa & 0.40 & 3.0 \\
\hline Dominican Republic & 0.49 & 8.8 & Indonesia & 1.02 & 1.3 \\
\hline Lithuania & 1.62 & 2.9 & China & 2.68 & 1.0 \\
\hline Canada & 3.52 & 1.2 & Israel & 0.37 & 2.1 \\
\hline Armenia & 0.69 & 8.6 & Ukraine & 0.28 & 1.7 \\
\hline Colombia & 2.73 & 1.3 & Oman & 0.38 & 2.4 \\
\hline Belgium & 1.3 & 2.8 & Brunei Darussalam & 0.48 & 0.5 \\
\hline Albania & 1.16 & 14.0 & El Salvador & 0.22 & 5.1 \\
\hline Botswana & 0.89 & 6.2 & Nicaragua & 0.22 & 3.8 \\
\hline Romania & 2.98 & 1.1 & India & 1.00 & 1.0 \\
\hline Poland & 1.41 & 2.2 & Mexico & 0.23 & 1.3 \\
\hline Costa Rica & 0.53 & 6.4 & Bosnia And Herzegovina & 0.14 & 4.0 \\
\hline
\end{tabular}

There are no complete 2014 dates in the case of Cabo Verde, Slovakia, Lebanon, Tonga, Vietnam, Guyana, Gambia, Suriname, Mongolia, and Honduras. Source: own work. Data source: World Tourism Organization.

\subsection{Countries with a Low Tourism Intensity Index}

The countries classified as having a low TII are listed in Table 9.

Table 9. Low Tourism Intensity Index (mean value 1995-2015).

\begin{tabular}{cccc}
\hline COUNTRY & TII & COUNTRY & TII \\
\hline & Mean Value 1995-2015 & & Mean Value 1995-2015 \\
\hline Comoros & 98 & Kuwait & 39 \\
The Former Yugoslav & 97 & Malawi & 38 \\
Republic of Macedonia & 95 & Togo & 38 \\
Syrian Arab Republic & 93 & Madagascar & 37 \\
Lesotho & 92 & Yemen & 33 \\
Guatemala & 86 & Mali & 30 \\
Azerbaijan & 85 & Cameroon & 28 \\
Senegal & 84 & Guinea-Bissau & 24 \\
Rwanda & Timor-Leste & 23 \\
Russian Federation & 83 & Burkina Faso & 23 \\
Kenya & 71 & Ethiopia & 21 \\
Serbia & Sierra Leone & 21 \\
Solomon Islands & 69 & Côte D'Ivoire & 17 \\
Zambia & 69 & Algeria & 16 \\
Bhutan & 67 & Chad & 15 \\
Bolivarian Republic of Venezuela & 66 & Congo & 14 \\
Plurinational State of Bolivia & 64 & Niger & 14 \\
Republic of Moldova & 60 & Pakistan & 11 \\
Haiti & 57 & Papua New Guinea & 10 \\
Peru & 57 & Angola & 9 \\
Belarus & 56 & Burundi & 8 \\
Paraguay & 54 & Sudan & 8 \\
Sri Lanka & 53 & Myanmar & 8 \\
Nepal & 48 & Bangladesh & 4 \\
Uganda & 47 & the Congo & 2 \\
Ghana & 46 & & 1 \\
Benin & 45 & Central African Republic & \\
Djibouti & 41 & & \\
& & &
\end{tabular}


In Table 10, the five-year evolution of the TII from 1995 to 2015 can be appreciated for the countries with a mean less than 100; many are excluded from the classification, due to a lack of data available in the WTO for the period analysed.

Table 10. Five-year evolution of the low Tourism Intensity Index.

\begin{tabular}{|c|c|c|c|c|c|}
\hline COUNTRY & 1995 & 2000 & 2005 & 2010 & 2015 \\
\hline Comoros & 156 & 112 & 93 & 74 & \\
\hline The Former Yugoslav Republic of Macedonia & & 101 & 78 & 100 & 140 \\
\hline Syrian Arab Republic & 85 & 82 & 98 & 201 & \\
\hline Lesotho & 89 & & & 89 & \\
\hline Guatemala & & & & 97 & 84 \\
\hline Azerbaijan & & & 45 & 88 & \\
\hline Senegal & 76 & 71 & 92 & 96 & \\
\hline Rwanda & & 28 & & 82 & 119 \\
\hline Russian Federation & 70 & 86 & 71 & 70 & 85 \\
\hline Kenya & 123 & 67 & 81 & 82 & \\
\hline Serbia & & & 43 & 82 & 121 \\
\hline Solomon Islands & 89 & 24 & 31 & 103 & \\
\hline Zambia & & 59 & 103 & 78 & \\
\hline Bolivarian Republic of Venezuela & & & & 61 & \\
\hline Bhutan & 28 & 35 & 41 & 93 & \\
\hline Plurinational State of Bolivia & 52 & 42 & 82 & 66 & 79 \\
\hline Republic of Moldova & & & & 56 & 64 \\
\hline Haiti & 61 & 47 & 27 & 73 & \\
\hline Peru & 32 & 44 & 60 & 69 & \\
\hline Belarus & & & 34 & 60 & 77 \\
\hline Paraguay & 92 & 48 & 46 & 58 & 99 \\
\hline Sri Lanka & 57 & 44 & 52 & 50 & \\
\hline Nepal & 69 & 56 & 30 & 44 & \\
\hline Uganda & 23 & 30 & 48 & 73 & \\
\hline Ghana & 20 & & & 56 & \\
\hline Benin & 68 & 42 & 42 & 42 & \\
\hline Djibouti & 42 & 41 & 35 & & \\
\hline Kuwait & 51 & 41 & 28 & 35 & \\
\hline Malawi & 40 & 36 & 38 & 35 & \\
\hline Togo & 23 & 20 & 24 & 60 & \\
\hline Madagascar & 31 & 39 & 43 & 35 & \\
\hline Yemen & 9 & 10 & 22 & 82 & \\
\hline Mali & & & & 34 & \\
\hline Cameroon & 18 & 31 & 21 & 27 & \\
\hline Guinea-Bissau & & & 5 & 28 & \\
\hline Timor-Leste & & & & 28 & \\
\hline Burkina Faso & & 19 & 22 & 28 & \\
\hline Ethiopia & 17 & 14 & 20 & 33 & \\
\hline Sierra Leone & 35 & 15 & 32 & 16 & \\
\hline Côte D'Ivoire & & & & 20 & \\
\hline Algeria & 8 & 14 & 25 & 21 & \\
\hline Chad & 20 & 14 & & & \\
\hline Congo & 22 & 10 & 15 & 0 & \\
\hline Niger & 8 & 15 & 13 & 18 & \\
\hline Pakistan & 13 & 11 & 11 & 11 & \\
\hline Papua New Guinea & 15 & 9 & & & \\
\hline Angola & & 7 & 11 & & \\
\hline Burundi & 8 & 6 & 10 & 8 & 6 \\
\hline Sudan & 2 & 1 & 9 & 8 & \\
\hline Central African Republic & 12 & 8 & 7 & & \\
\hline Myanmar & 6 & 4 & & & \\
\hline Bangladesh & 2 & 3 & 3 & 3 & \\
\hline Democratic Republic of the Congo & & & 1 & 1 & \\
\hline
\end{tabular}


From Table 11, it can be deduced that, within the group, the country with the greatest economic dependence is the Solomon Islands, followed by Bhutan, Togo, and Sri Lanka. In no case is significant demographic pressure visible.

Table 11. Basic components of the low TII.

\begin{tabular}{|c|c|c|c|c|c|}
\hline & $\begin{array}{l}\text { (Tourism/ } \\
\text { Population) } \\
\text { (Ti/Pi) }\end{array}$ & $\begin{array}{c}\text { Tourism } \\
\text { Revenue/ GDP } \\
\text { (TRi/GDPi)_\% }\end{array}$ & & $\begin{array}{l}\text { (Tourism/ } \\
\text { Population) } \\
\text { (Ti/Pi) }\end{array}$ & $\begin{array}{c}\text { Tourism } \\
\text { Revenue/ GDP } \\
\text { (TRi/GDPi)—\% }\end{array}$ \\
\hline COUNTRY & 2014 & 2014 & COUNTRY & 2014 & 2014 \\
\hline $\begin{array}{l}\text { The Former Yugoslav } \\
\text { Republic of Macedonia }\end{array}$ & 0.20 & 2.6 & Belarus & 0.11 & 1.6 \\
\hline Guatemala & 0.09 & 2.7 & Paraguay & 0.10 & 0.1 \\
\hline Azerbaijan & 0.22 & 3.6 & Sri Lanka & 0.07 & 4.4 \\
\hline Senegal & 0.07 & 3.1 & Nepal & 0.03 & 2.6 \\
\hline Rwanda & 0.08 & 3.7 & Benin & 0.02 & 1.7 \\
\hline Russian Federation & 0.23 & 1.0 & Kuwait & 0.05 & 0.4 \\
\hline Kenya & 0.03 & 3.0 & Malawi & 0.05 & 0.6 \\
\hline Serbia & 0.12 & 3.1 & Togo & 0.04 & 5.1 \\
\hline Solomon Islands & 0.04 & 6.2 & Mali & 0.01 & 1.8 \\
\hline Zambia & 0.06 & 2.4 & Burkina Faso & 0.01 & 1.5 \\
\hline $\begin{array}{c}\text { Bolivarian Republic of } \\
\text { Venezuela }\end{array}$ & 0.51 & 0.1 & Sierra Leone & 0.01 & 0.7 \\
\hline Bhutan & 0.18 & 6.1 & Algeria & 0.06 & 0.2 \\
\hline $\begin{array}{c}\text { Plurinational State of } \\
\text { Bolivia }\end{array}$ & 0.08 & 2.2 & Burundi & 0.02 & 0.2 \\
\hline Republic of Moldova & 0.03 & 3.9 & Bangladesh & 0.00 & 0.1 \\
\hline Peru & 0.10 & 1.9 & & & \\
\hline
\end{tabular}

There are no complete 2014 dates in the case of Comoros, Syrian Arab Republic, Lesotho, Haiti, Uganda, Ghana, Djibouti, Madagascar, Yemen, Cameroon, Guinea-Bissau, Timor-Leste, Ethiopia, Cote d'Ivore, Chad, Congo, Niger, Pakistan, Papua New Guinea, Angola, Sudan, Central African Republic, Myanmar, and Democratic Republic of the Congo. Source: own work. Data source: World Tourism Organization.

The classification demonstrates the relevance of the Caribbean as a key area in global tourism intensity, a reality that describes its nature of island economies [36,55].

Below, we present the calculation of the Tourism Density (TD) for all the countries from 1995 to 2015. With these data, a ranking was drawn up from greater to lower tourism density, based on the mean value of the indicator in this period, and the countries were classified according to whether they have very high TD (mean greater than 10,000 tourists per $\mathrm{km}^{2}$ ), high TD (mean less than 10,000 tourists per $\mathrm{km}^{2}$ and over 1000 tourists per $\mathrm{km}^{2}$ ), medium TD (mean less than 1000 tourists per $\mathrm{km}^{2}$ and greater than 300 tourists per $\mathrm{km}^{2}$ ), or low TD (mean less than 300 tourists per $\mathrm{km}^{2}$ and greater than 100 tourists per $\mathrm{km}^{2}$ ), enabling us to obtain, in turn, four large blocks of countries.

In Figure 2, the evolution of Tourism Density, from 1995 to 2015, can be observed in Macau-the country with the greatest tourism density in the world—far greater than the next two, which are Hong Kong and Singapore. Macau goes from a tourism density of 210,100 tourists per km² in 1995 to 480,726 tourists in 2014 (there are no data available for 2015), representing $128.8 \%$ growth over this period.

Far behind, but still classified as having very high tourism density, we find Hong Kong and Singapore, whose evolution from 1995 to 2015 is shown in Figure 3. Hong Kong goes from a density of 6532 tourists per $\mathrm{km}^{2}$ in 1998 to 25,183 tourists per $\mathrm{km}^{2}$ in 2014, namely, 285.5\% growth over the period (Table 13). Singapore goes from 9034 tourists per $\mathrm{km}^{2}$ in 1995 to 16,390 in 2014, up 81\% (Table 13). 


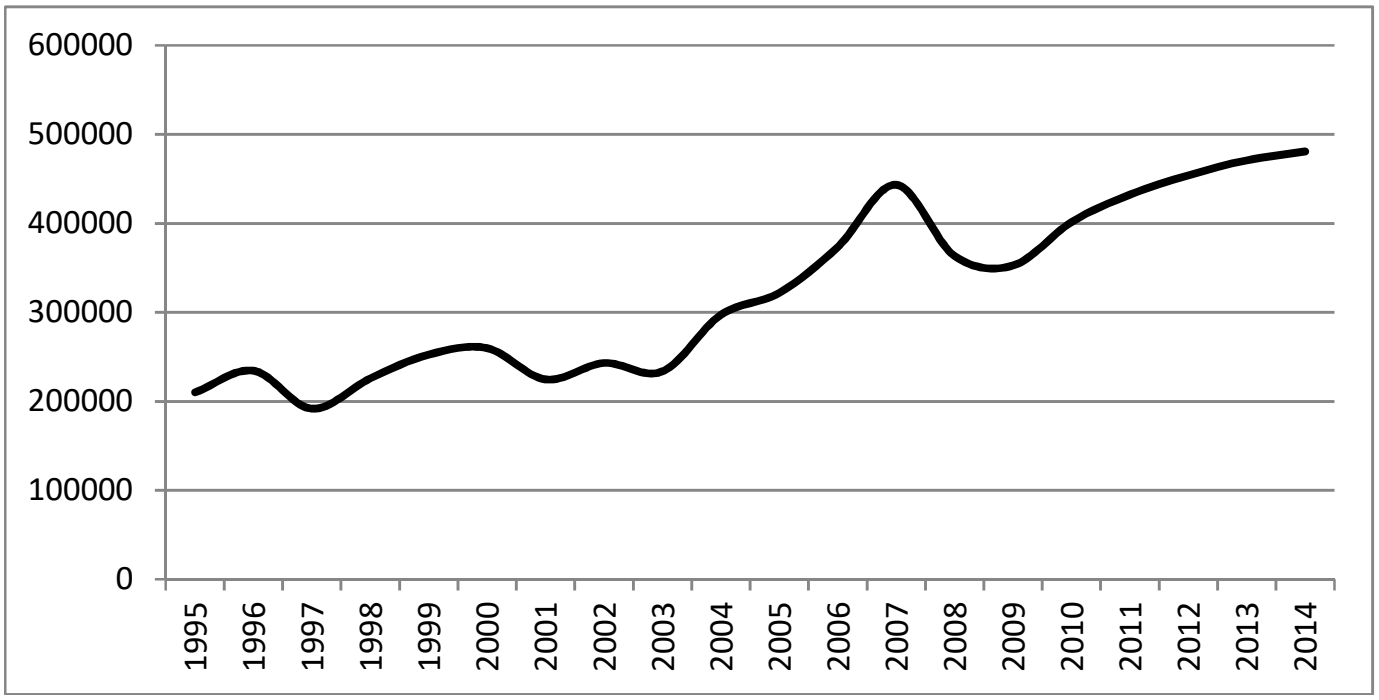

Figure 2. Tourism Density in Macao. Source: own work. Data source: World Tourism Organization and World Bank.

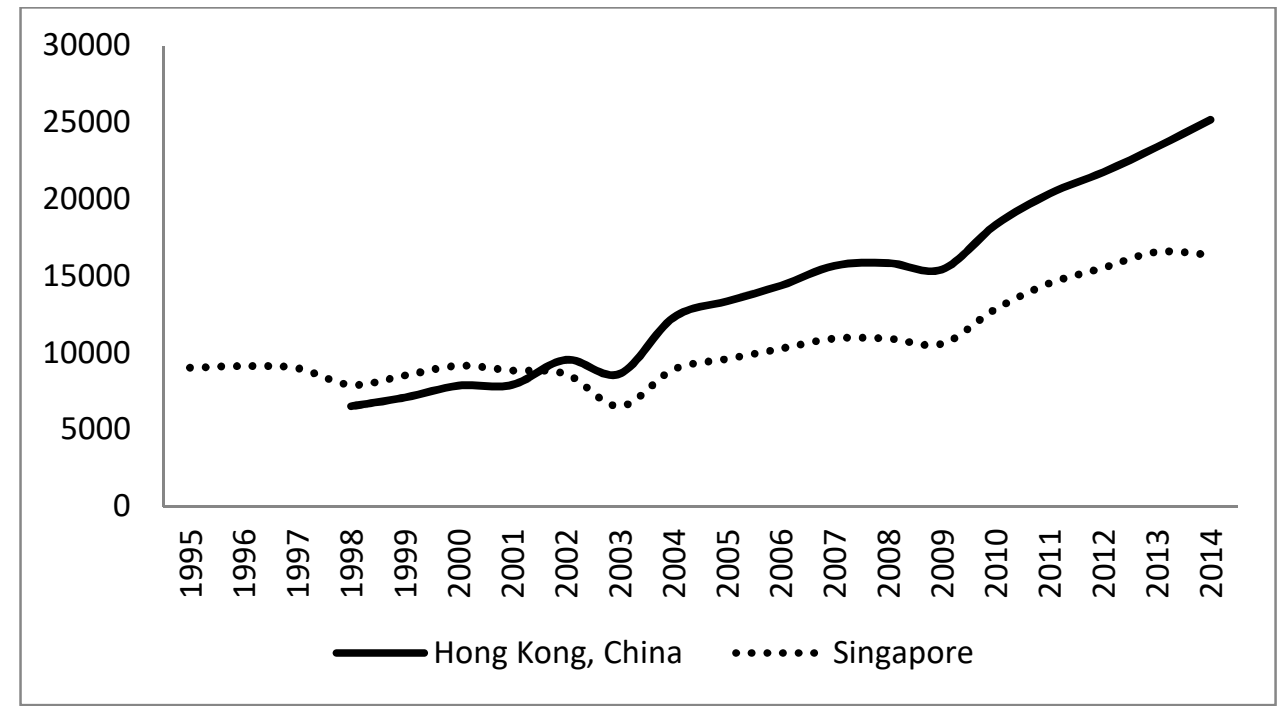

Figure 3. Very high Tourism Density. Source: own work. Data source: World Tourism Organization and World Bank.

In Figure 4, the evolution of density from 1995 to 2015 is revealed for the set of countries that were classified as having high Tourism Density.

The classification was drawn up based on the mean tourism density value between 1995 and 2015. It must be remembered that, in the case of high tourism density, the mean value must be less than 10,000 tourists per $\mathrm{km}^{2}$ and over 1000 tourists per $\mathrm{km}^{2}$. As it is a mean value for the whole 20-year period, some values greater than 10,000 tourists per $\mathrm{km}^{2}$ can be found in Figure 4, as this is not a mean value but, rather, the specific value for the corresponding year. Leading this group is Bahrain, which goes from a density of 3255 tourists per $\mathrm{km}^{2}$ in 1995 to 13,556 tourists per $\mathrm{km}^{2}$ in 2014, representing $216.5 \%$ growth (Table 13). The evolution of tourism density is very different among the countries classified as having high tourism density. At one end, we find the Maldives, whose tourism density increased 327.6\% between 1995 and 2014; and at the other end, is Japan, which decreased 18.3\% between 2008 and 2014 (in this figure, the impact of the earthquake in 2011—the strongest recorded in Japanese history—can be clearly seen). 


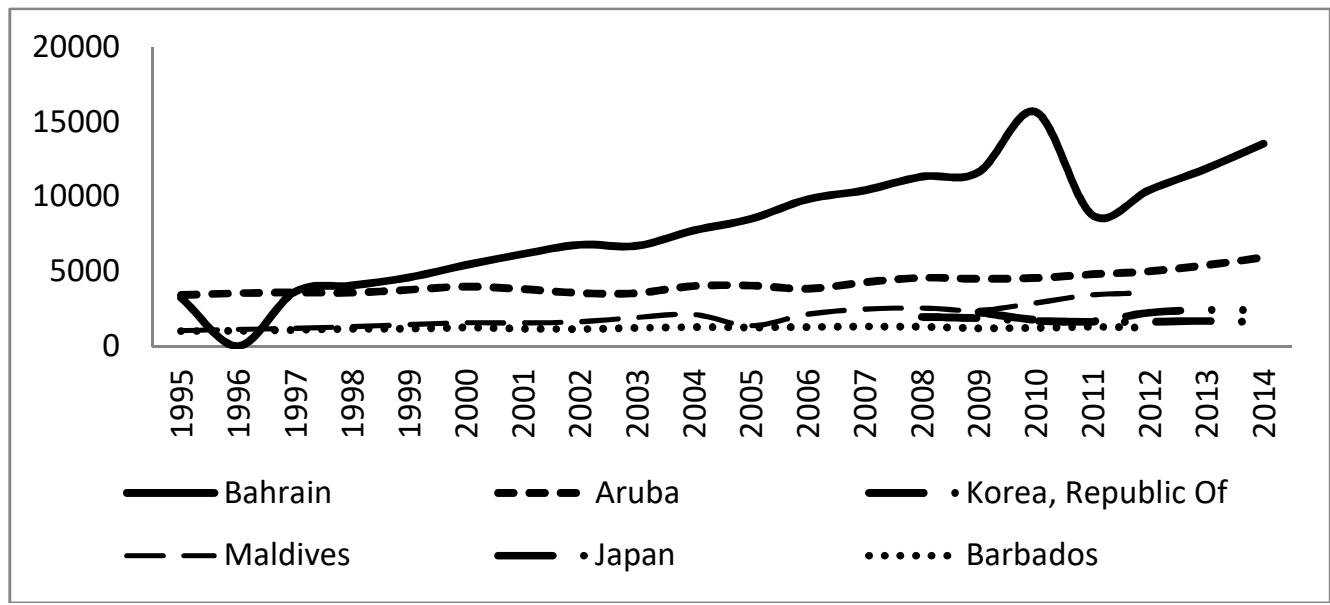

Figure 4. High Tourism Density. Source: own work. Data source: World Tourism Organization and World Bank.

In Table 12, the five-year evolution, between 1995 and 2015, is outlined for the Tourism Density of the set of countries classified as having medium tourism density. In this group, we find all the countries whose average tourism density over the period considered is less than 1000 tourists per $\mathrm{km}^{2}$ and greater than 300 tourists per $\mathrm{km}^{2}$.

Table 12. Five-year evolution of the medium Tourism Density.

\begin{tabular}{ccccccc}
\hline COUNTRY & $\mathbf{1 9 9 5}$ & $\mathbf{2 0 0 0}$ & $\mathbf{2 0 0 5}$ & $\mathbf{2 0 1 0}$ & $\mathbf{2 0 1 4}$ & Average (1995-2014) \\
\hline United Kingdom & & & & 607 & 605 & 627 \\
Antigua and Barbuda & 500 & 470 & 557 & 523 & & 538 \\
$\quad$ France & & & 537 & 509 & 527 & 530 \\
Czech Republic & & & 437 & 458 & 477 & 461 \\
$\quad$ Saint Lucia & 373 & 435 & 513 & 494 & 545 & 455 \\
$\quad$ Belgium & & & & 424 & 480 & 445 \\
$\quad$ Spain & & 380 & 419 & 392 & 406 & 399 \\
$\quad$ Cyprus & & & 390 & & 404 & 393 \\
$\quad$ Italy & 384 & 410 & 410 & 333 & 389 \\
Saint Kitts and Nevis & 304 & 281 & 542 & 377 & 435 & 383 \\
Switzerland & & & & 368 & 379 & 378 \\
Luxembourg & & & & 329 & 441 & 372 \\
$\quad$ Mauritius & 206 & 322 & 375 & 459 & 506 & 355 \\
$\quad$ Grenada & 318 & 379 & 291 & 324 & 394 & 319 \\
Seychelles & 258 & 283 & 262 & 367 & 483 & \\
\hline
\end{tabular}

Source: own work. Data source: World Tourism Organization and World Bank.

European countries appear, for the first time, in the classification: England, France, the Czech Republic, Belgium, Spain, Cyprus, Italy, Switzerland, and Luxembourg. Table 13 shows the evolution of tourism density, which is very different among the European countries classified in the group of medium tourism density. On the one hand, we find Spain, whose density increased $27.8 \%$ from 1999 to 2014, going from 318 tourists per $\mathrm{km}^{2}$ to 406 tourists per $\mathrm{km}^{2}$; and, on the other hand, we find Switzerland, with a drop of $10.5 \%$ between 1998 and 2014, from 423 tourists per $\mathrm{km}^{2}$ to 379 per $\mathrm{km}^{2}$. 
Table 13. Evolution of Tourism Density.

\begin{tabular}{|c|c|c|c|c|c|c|}
\hline COUNTRY & $\begin{array}{l}\text { Tourism } \\
\text { Density }\end{array}$ & $\begin{array}{l}\text { Initial Year } \\
\text { Considered }\end{array}$ & $\begin{array}{l}\text { Final Year } \\
\text { Considered }\end{array}$ & $\begin{array}{c}\text { Initial Tourism } \\
\text { Density }\end{array}$ & $\begin{array}{c}\text { Final Tourism } \\
\text { Density }\end{array}$ & Growth \\
\hline India & Low & 1995 & 2014 & 42 & 393 & 830.0 \\
\hline China & Low & 1995 & 2014 & 67 & 382 & 473.5 \\
\hline Maldives & High & 1995 & 2014 & 1.054 & 4.506 & 327.6 \\
\hline Bahrain & High & 1995 & 2014 & 3.255 & 13.556 & 316.5 \\
\hline Macao, China & Very High & 1995 & 2014 & 210.100 & 480.726 & 128.8 \\
\hline Lebanon & Low & 1997 & 2013 & 53 & 122 & 128.3 \\
\hline Philippines & Low & 2009 & 2014 & 174 & 374 & 114.8 \\
\hline Malaysia & Low & 2008 & 2014 & 155 & 300 & 92.8 \\
\hline Seychelles & Medium & 1995 & 2014 & 258 & 483 & 86.9 \\
\hline Singapore & Very High & 1995 & 2014 & 9.034 & 16.390 & 81.4 \\
\hline Saint Lucia & Medium & 1995 & 2014 & 373 & 545 & 46.3 \\
\hline Saint Kitts and Nevis & Medium & 1995 & 2014 & 304 & 435 & 43.0 \\
\hline Israel & Low & 1995 & 2014 & 104 & 137 & 31.5 \\
\hline Colombia & Low & 2009 & 2014 & 89 & 114 & 27.9 \\
\hline Spain & Medium & 1999 & 2014 & 318 & 406 & 27.8 \\
\hline Slovenia & Low & 2000 & 2014 & 167 & 212 & 26.5 \\
\hline Indonesia & Low & 2006 & 2014 & 110 & 136 & 24.5 \\
\hline Grenada & Medium & 1995 & 2014 & 318 & 394 & 24.1 \\
\hline Turkey & Low & 2009 & 2014 & 116 & 141 & 21.6 \\
\hline Barbados & High & 1995 & 2012 & 1.028 & 1.247 & 21.3 \\
\hline Belgium & Medium & 2009 & 2014 & 399 & 480 & 20.3 \\
\hline $\begin{array}{l}\text { Saint Vincent and } \\
\text { The Grenadines }\end{array}$ & Low & 1995 & 2014 & 154 & 182 & 18.3 \\
\hline Italy & Medium & 1997 & 2014 & 310 & 333 & 7.4 \\
\hline Republic of Korea & High & 2009 & 2014 & 2.294 & 2.423 & 5.6 \\
\hline Poland & Low & 2005 & 2014 & 162 & 171 & 5.4 \\
\hline Greece & Low & 2004 & 2014 & 184 & 193 & 4.8 \\
\hline United States of America & Low & 2007 & 2014 & 214 & 222 & 3.8 \\
\hline Czech Republic & Medium & 2003 & 2014 & 464 & 477 & 2.8 \\
\hline France & Medium & 2005 & 2014 & 537 & 527 & -1.9 \\
\hline Slovakia & Low & 2005 & 2013 & 246 & 236 & -4.2 \\
\hline United Kingdom & Medium & 2009 & 2014 & 634 & 605 & -4.4 \\
\hline Switzerland & Medium & 1998 & 2014 & 423 & 379 & -10.5 \\
\hline Bahamas & Low & 1995 & 2014 & 115 & 103 & -10.7 \\
\hline Hungary & Low & 2008 & 2014 & 328 & 289 & -11.8 \\
\hline Japan & High & 2008 & 2014 & 1.977 & 1.615 & -18.3 \\
\hline
\end{tabular}

Source: own work. Data source: World Tourism Organization and World Bank.

Finally, in Table 14, it is possible to see the evolution of tourism density between 1995 and 2015 for the countries classified as having low tourism density. The mean of the indicator for the period considered is less than 300 tourists per $\mathrm{km}^{2}$, and greater than 100 tourists per $\mathrm{km}^{2}$.

Standing out in this group of countries with low tourism density, we find India, Qatar, and China, which have undergone the greatest rise in tourism density in the period of study out of all the countries analysed. India went from 42 tourists per $\mathrm{km}^{2}$ in 1995 to 393 tourists per $\mathrm{km}^{2}$ in 2014, representing $830 \%$ growth (Table 13). Qatar evolved from 31 tourists per $\mathrm{km}^{2}$ in 1999 to 243 tourists per km² in 2014, up $691.6 \%$. China, with 67 tourists per $\mathrm{km}^{2}$ in 1995, reached 382 tourists per $\mathrm{km}^{2}$ in 2014, representing a rise of $473.5 \%$. 
Table 14. Five-year evolution of the low Tourism Density.

\begin{tabular}{|c|c|c|c|c|c|c|}
\hline COUNTRY & 1995 & 2000 & 2005 & 2010 & 2014 & $\begin{array}{c}\text { Average } \\
(1995-2014)\end{array}$ \\
\hline Croatia & & & & 263 & 300 & 280 \\
\hline Philippines & & & & 211 & 374 & 270 \\
\hline Slovakia & & & 246 & 209 & & 237 \\
\hline Thailand & & & & 229 & & 230 \\
\hline Malaysia & & & & 207 & 300 & 226 \\
\hline Ireland & & & & 203 & 250 & 224 \\
\hline United States of America & & & & 205 & 222 & 210 \\
\hline $\begin{array}{c}\text { Saint Vincent and the } \\
\text { Grenadines }\end{array}$ & 154 & 187 & 246 & 185 & 182 & 194 \\
\hline Greece & & & 211 & 152 & 193 & 191 \\
\hline Slovenia & & 167 & 173 & 190 & 212 & 185 \\
\hline China & 67 & 81 & 131 & 225 & 382 & 161 \\
\hline Poland & & & 162 & 146 & 171 & 159 \\
\hline India & 42 & 68 & 120 & 229 & 393 & 152 \\
\hline Jamaica & 104 & 120 & 135 & 175 & 189 & 141 \\
\hline Turkey & & & & 127 & 141 & 129 \\
\hline Indonesia & & & & 126 & 136 & 126 \\
\hline Lebanon & & 71 & 109 & 207 & & 110 \\
\hline Bahamas & 115 & 111 & 116 & 99 & 103 & 108 \\
\hline Qatar & & 33 & 79 & & 243 & 105 \\
\hline Colombia & & & & 105 & 114 & 105 \\
\hline Israel & 104 & 115 & 90 & 130 & 137 & 100 \\
\hline
\end{tabular}

Source: own work. Data source: World Tourism Organization and World Bank.

\section{Conclusions}

First of all, the main aim of this research was to design an index to calculate tourism intensity, a key concept for any tourism destination, as it can affect the wellbeing of both residents and the tourists themselves. We established this by consulting the databases of the UNWTO for the period 1995-2015, using four determining vectors: the GDP, tourism spending, the population, and the number of tourists. We thereby built a compound index that is more convincing than tourism analysis using only one of the aforementioned indicators. However, our aim was above all descriptive, without going into-which would require considerable length - the economic characteristics of the groups of countries we were able to group together, based on the calculation of the TII. Classifying a destination according to whether it has a very high, high, medium, or low tourism intensity, may be useful when it comes to determining the type of policies that must be defined in order to eliminate negative externalities and to boost positive ones. Along these lines, we believe an analysis of tourism densities (TD) is also important, and we put forward a second proposal for measuring tourism intensity based on a specific formula, with data from the TII and from the World Bank. Both methodologies enabled different rankings to be drawn up, broken down according to tourism intensity, with some specific parameters: very high, high, medium, and low.

Secondly, it is emphasised that the region with the highest tourism intensity in the world is Macau, a destination that focuses its economy on gambling, as it boasts numerous casinos in its territory. The TII is 6656, the mean between 1995 and 2015 (100 would be the mean world value), with a TD of 48,726 tourists per $\mathrm{km}^{2}$ in 2014. The case of Macau is not unique; in fact, another relevant conclusion is that island economies are the ones with the greatest TII. In this regard, the present study follows the lines marked in a previous one [36], in which it was also determined that the highest tourism densities in the world were found in archipelagos and, specifically, in the Cayman Islands, British Virgin Islands, and the Balearic Islands.

Thirdly, we can affirm that the changes taking place in tertiary economies in the process of economic globalisation are very fast. The different tourism intensities will, undoubtedly, condition 
regulations of all kinds: urban, fiscal, and pertaining to the tourism industry itself. Hence, the importance, decisive in our opinion, of measuring tourism economy with tools that are innovative (the use of bioeconomy criteria is another key research path to studying the evolution of tourism economies more accurately, based on biophysical indicators that affect sustainability processes; see [56-63]). Based on this observation, a whole range of opportunities for, and threats to, tourism economies open up. As for the former, the dynamic competitiveness of the productive systems consists not only of the ability to adapt to changes in demand, but to do so in the shortest possible time. Indeed, the speed with which local actors process and put information into practice is crucial, and this can be boosted through cooperation between the different productive units. The agility whereby this information is systematised is related to three essential factors, amongst others: firstly, the productive resources of companies, depending on their critical mass or size; secondly, human capital and the implementation of regional and local innovation systems, since their availability may favour finding new possibilities of efficient productive combinations, in order to respond to changes in demand; finally, the function of leadership, which the public sector would have to take on with effective synergies with private capital.

We would like to highlight the fact that the empirical precision of tourism intensity, quite apart from perceptions that are subjective or have clear political intentions, is what we are seeking in this line of research, with the result of drawing up the Tourism Intensity Index (TII) and the Tourism Density index (TD). They have two main potentials: they enable a homogeneous comparison, using four main indicators that come from institutions with open consultation databases-the UNWTO and the World Bank; and they determine a specific numerical magnitude which, at least, eschews subjective observation which, despite always being respectable, may be biased.

The tourist intensity is affecting many regions specialized in the leisure industry. These are factors of concern: problems of demographic congestion, high consumption of natural and energy resources, ecological impacts that affect the landscape, and even our own cultural values. All these elements, which are clearly sensed in our research, force policy makers to act in very clear directions. The most important, without a doubt, will be the environmental sustainability of the tourist territory. This territory is the main context, the basic natural capital that is a claim for visitors. We understand that magical recipes cannot be given in economic policy. However, at the same time, we think that the objectives to be achieved would be to encourage renewable energies, a strong technological renovation that makes processes more efficient (production of electricity by photovoltaic means, for example), the possibility of promoting a specific environmental taxation for tourism and, last but not least, betting on the formation of a human capital specialized in mass tourism in all its aspects.

Lastly, our results are of a macroeconomic nature, and are usually assigned to nation states. However, we think that, as research assumptions, the indices and the methodology we have constructed would be equally applicable to a more regional-scale analysis. The sustainability of tourism should be treated from regional perspectives (as has also happened with studies of economic history in the industrial field). This is why this can be a good line of future research: the disaggregation of data on a regional scale. Now, the research that is developed in the future will have the limits that will be marked by the availability of statistical records. This is fundamental. However, at the same time, the proportion of these new measurement indices can be contrasted with others that should be investigated. In this sense, we are working on the preparation of biophysical indicators for the tourist economy, which will complement the two indices presented in this work.

Author Contributions: C.M. develops the methodological part of the paper defining the indexes and E.V. performs the calculations of the defined indices. The writing of the article and the conclusions has been elaborated jointly. And all authors read and approved the final manuscript.

Funding: This work inserts in the project of research Crisis industrial y recuperación productiva en la historia de España, 1686-2018, HAR2015-64769-P, directed by Jordi Catalan. Dirección General de Investigación, Ministerio de Economía y Competitividad.

Conflicts of Interest: The authors declare no conflict of interest. 


\section{References}

1. Milano, C.; Novelli, M.; Eastbourne, U.K.; Cheer, J.M. Tourism Planning and Development Journal Special Issue on: Overtourism and Tourismphobia: A Journey through Four Decades' of Tourism Development, Planning and Local Concerns. Available online: https: / www.researchgate.net/publication/ 321873167_CALL_FOR_PAPERS_Overtourism_and_Tourismphobia_A_journey_through_four_decades $\backslash$ T1 \textquoteright_of_tourism_development_planning_and_local_concerns/citations (accessed on 22 November 2018).

2. Getz, D. Tourism planning and destination life cycle. Ann. Tour. Res. 1992, 19, 752-770. [CrossRef]

3. Gonçalves, V.; Aguas, P. The concept of life cycle: An application to the tourist product. J. Travel Res. 1997, 35, 12-22. [CrossRef]

4. Tokarchuk, O.; Gabriele, R.; Maurer, O. Tourism intensity impact on satisfaction with life of German residents. Tour. Econ. 2016, 22, 1315-1331. [CrossRef]

5. Spinalis, I.; Kizos, T.; Karampela, S.; Vayanni, H. A tourism tipology of the Greek Islands. In Proceedings of the International Conference of Trends, Impacts and Policies on Tourism Development, Heraklion, Greece, 15-18 June 2006; Hellenic Open University: Patras, Greece, 2006.

6. Albalate, D.; Bel, G. Tourism and urban public transport: Holding demand pressure under supply constraints. Tour. Manag. 2010, 31, 425-433. [CrossRef]

7. Butler, R.W. The concept of tourism area cycle of evolution: Implications for management of resources. Can. Geogr. 1980, 24, 5-12. [CrossRef]

8. Ioannides, D. Strengthening the ties between tourism and economic geography: A theoretical agenda. Prof. Geogr. 1995, 47, 49-60. [CrossRef]

9. Agarwal, S. The resort cycle and seaside tourism: An assessment of its applicability and validity. Tour. Manag. 1997, 18, 65-73. [CrossRef]

10. Agarwal, S. Restructuring seaside tourism. The resort lifecycle. Ann. Tour. Res. 2002, 29, 25-55. [CrossRef]

11. Berry, E.N. An Application of Butler's Tourism Area Life Cycle to the Cairns Region, Australia (1876-1998). Ph.D. Thesis, School of Tropical Environment Studies and Geography, James Cook University of North Queensland, Cairns, Australia, 2001.

12. Hovinen, G. Revisiting the destination life cycle model. Ann. Tour. Res. 2002, 29, 209-230. [CrossRef]

13. Garay Tamajón, L. El Ciclo de Evolución del Destino Turístico. Una Aproximación al Desarrollo Histórico del Turismo en Cataluña. Ph.D. Thesis, Universitat Autònoma de Barcelona, Barcelona, Spain, 2007.

14. Gross, S.; Weber, F.; Stettler, J.; Priskin, J.; Rosenberg-Taufer, B.; Ponnapureddy, S.; Fux, S.; Camp, M.A.; Barth, M. Tourism Destinations under Pressure. Challenges and Innovative Solutions; Working Paper; Lucerne University of Applied Sciences and Arts Institute of Tourism: Lucerne, Switzerland, 2017.

15. Sharpley, R. Tourism and Sustainable Development: Exploring the Theoretical Divide. J. Sustain. Tour. 2000, 8,1-19. [CrossRef]

16. Liu, Z. Sustainable Tourism Development: A Critique. J. Sustain. Tour. 2003, 11, 459-475. [CrossRef]

17. OMT. Indicators of Sustainable Development for Tourism Destinations: A Guidebook; OMT: Madrid, Spain, 2004.

18. Weaver, D. Can sustainable tourism survive climate change? J. Sustain. Tour. 2011, 19, 5-15. [CrossRef]

19. Burghelea, C.; Uzlău, C.; Ene, C.M. Comparative indicators of Sustainable Tourism. Available online: http:/ / managementjournal.usamv.ro/pdf/vol.16_3/Art9.pdf (accessed on 22 November 2018).

20. Zientara, P.; Zamojska, A. Green organitzational climates and employee pro-environmental behavior in the hotel industry. J. Sustain. Tour. 2016, 26, 1142-1159. [CrossRef]

21. De Jong, A.; Varley, P. Foraging tourism: Critical moments in sustainable consumption. J. Sustain. Tour. 2018, 26, 685-701. [CrossRef]

22. Moyle, C.L.J.; Moyle, B.D.; Chai, A.; Hales, R.; Banhalmi-Zakar, Z.; Bec, A. Have Australia's tourism strategies incorporated climate change? J. Sustain. Tour. 2018, 26, 703-721. [CrossRef]

23. Bramwell, B.; Lane, B. Sustainable Tourism: An Evolving Global Approach. J. Sustain. Tour. 1993, 1, 1-5. [CrossRef]

24. Butler, R.W. Sustainable tourism: A state-of-the-art review. Tour. Geogr. 1999, 1, 7-25. [CrossRef]

25. Pulido-Fernández, J.I.; Cárdenas-García, P.J.; Villanueva-Álvaro, J.J. The role of environmental sustainability in the transformation of tourism growth into economic development. Environ. Eng. Manag. J. 2013, 12, 2009-2018. [CrossRef] 
26. Boluk, K.; Cavaliere, C.T.; Higgins-Desbiolles, F. Critical thinking to realize sustainability in tourism systems: Reflecting on the 2030 sustainable development goals. J. Sustain. Tour. 2017, 25, 1201-1204. [CrossRef]

27. Pulido-Fernández, J.I.; López-Sánchez, Y. Are Tourists Really Willing to Pay More for Sustainable Destinations? Available online: https://www.mdpi.com/2071-1050/8/12/1240/htm (accessed on 22 November 2018).

28. Pulido-Fernández, J.I.; Pulido-Fernández, M.C. Proposal for an indicators system of governance in tourism destinations. Soc. Indic. Res. 2018, 137, 695-743. [CrossRef]

29. Font, X.; McCabe, S. Sustainability and marketing in tourism: Its contexts, paradoxes, approaches, challenges and potential. J. Sustain. Tour. 2018, 25, 869-883. [CrossRef]

30. Higham, J.; Miller, G. Transforming societies and transforming tourism: Sustainable tourism in times of change. J. Sustain. Tour. 2018, 26, 1-8. [CrossRef]

31. European Environment Agency. Indicator Fact Sheet Signals. Chapter Tourism; European Environment Agency: København, Denmark, 2001.

32. INTERREG IIIC. Intensity of Tourism; European Union: Brussels, Belgium, 2005.

33. INTERREG IVC. Sustain. Measuring Coastal Sustainability; European Union: Brussels, Belgium, 2012.

34. Gauche, M. Tourism Intensity at a Local Level: Environmental Pressure of Preservation Factor? Datalab, The Monitoring and Statistics Directorate: Gobierno de Francia, France, 2017.

35. Gauche, M. Measuring tourism intensity and its environmental impact. In Proceedings of the 6th UNWTO International Conference of Tourism Statistics Measuring Sustainable Tourism, Manila, Philippines, 19-24 June 2017.

36. Manera, C.; Navinés, F. La Indústria Invisible, 1950-2016. El Desenvolupament del Turisme a L'economia Balear; Lleonard Muntaner Editor: Palma, Spain, 2018.

37. Pérez-Dacal, D.; Pena-Boquete, Y.; Fernández, M. A Measuring Tourism Specialization: A Composite Indicator for the Spanish Regions. Alma Tour. 2014, 5, 35-73.

38. Pérez, C. Revoluciones Tecnológicas y Capital Financiero. Las Dinámicas de las Grandes Burbujas y las Épocas de Bonanza; Siglo XXI: Madrid, Spain, 2004.

39. Morley, C.L. A microeconomic theroy of international tourism demand. Ann. Tour. Res. 1992, 19, $250-267$. [CrossRef]

40. Apostolopoulos, Y.; Loukissas, P.; Leontidou, L. Mediterranean Tourism. Facets If Socioeconomic Development and Cultural Change; Roudlege: London, UK, 2001.

41. Segreto, L.; Manera, C.; Pohl, M. (Eds.) Europe at the Seaside. The Economic History of Mass Tourism in the Mediterranean; Berghan Books: New York, NY, USA; Oxford, UK, 2009.

42. Papatheodorou, A.; Song, H. International tourism forecasts: Time-series analysis of world and regional data. Tour. Econ. 2005, 11, 11-23. [CrossRef]

43. Agarwal, S.; Ball, R.; Shaw, G.; Williams, A. The geography of tourism production: Uneven disciplinary development. Tour. Geogr. 2000, 2, 241-263. [CrossRef]

44. Pulido-Fernández, J.I.; Cárdenas-García, P.J. Tourism as a tool of economic development in por countries. Tour. Intediscip. J. 2014, 62, 309-322.

45. OMT. Panorama OMT del Turismo Internacional; OMT: Madrid, Spain, 2017.

46. Garau, J. Tourist Satisfaction, Dissatisfaction and Place Attachment at Sun and Sand Mass Tourism Destinations; Ph.D. Thesis, Universitat de les Illes Balears, Palma, Spain, 2010.

47. OMT. Tourism Towards 2030. Global Overview; OMT: Madrid, Spain, 2011.

48. Alegre, J.; Pou, L.L. The Determinants of the Probability of Tourism Consumption: An Analysis with a Family Expenditure Survey; Working Papers; Departamento de Economía Aplicada de la Universitat de les Illes Balears: Palma, Spain, 2002.

49. Alegre, J.; Pou, L.L. La reducción del tiempo de estancia en los destinos vacacionales: Implicaciones sobre el gasto turístico y la estacionalidad en las Islas Baleares. G. López Casasnovas (Dir.). In Islas Baleares. Serie Estudios Regionales; Fundación BBVA: Madrid, Spain, 2003.

50. Britton, S. Tourism, Capital and Place: Towards a Critical Geography of Tourism. Available online: https: / /journals.sagepub.com/doi/10.1068/d090451 (accessed on 22 November 2018).

51. Britton, S. La economía política del turismo en el Tercer Mundo. In Los Mitos del Turismo; Jurdao, F., Ed.; Endymion: Madrid, Spain, 1992.

52. Poon, A. Tourism, Technology and Competitive Strategies; CAB International: Wallingford, UK, 1993. 
53. Turner, L.; Ash, J. La Horda Dorada. El Turismo Internacional y la Periferia del Placer; Endymion: Madrid, Spain, 1991.

54. Gormsen, E. The impact of tourism on coastal areas. Geojournal 1997, 42, 39-54. [CrossRef]

55. Wilkinson, P.F. Strategies for tourism in island microstates. Ann. Tour. Res. 1989, 16, 153-177. [CrossRef]

56. O'Reilly, A.M. Tourism carrying-capacity: Concept and issues. Tour. Manag. 1986, 7, 254-258. [CrossRef]

57. Pearce, D. Tourism Development; Longman: Harlow, UK, 1989.

58. Mowforth, M.; Munt, I. Tourism and Sustainability: New Tourism in the Third World; Routledge: London, UK, 1998.

59. Sindinga, I. Alternative tourism and sustainable development in Kenya. J. Sustain. Tour. 1999, 7, $108-127$. [CrossRef]

60. Twining-Ward, L.; Butler, R. Implementing sustainable tourism development on a small island: Development and the use of sustainable tourism development indicators in Samoa. J. Sustain. Tour. 2002, 19, 363-387. [CrossRef]

61. Gössling, S.; Hanssonb, C.B.; Hörstmeierc, O.; Sagge, S. Ecological footprint analysis as a tool to assess tourism sustainability. Ecol. Econ. 2002, 43, 2-3. [CrossRef]

62. Hall, M.C. Tourism urbanisation and global environmental change. In Tourism and Global Environmental Change. Ecological, Social, Economic and Political Interrelationships; Gössling, S., Hall, M., Eds.; Routledge: New York, NY, USA, 2006.

63. Pulido-Fernández, J.I.; Sánchez-Rivero, M. Measuring Tourism Sustainability. Proposal of a Composite Index. Tour. Econ. 2009, 15, 277-296. [CrossRef]

(C) 2018 by the authors. Licensee MDPI, Basel, Switzerland. This article is an open access article distributed under the terms and conditions of the Creative Commons Attribution (CC BY) license (http:/ / creativecommons.org/licenses/by/4.0/). 